\title{
Differentiation of the forms of oral candidiasis in the clinical context
}

\author{
Diferenţierea formelor de candidoză orală în contextul clinic \\ Horia LĂZĂRESCU ${ }^{1}$, Daniela MIRICESCU ${ }^{2}$, Andrei KOZMA ${ }^{1,7}$, Florica ŞANDRU ${ }^{3,4}$, \\ Ana Maria Alexandra STĂNESCU ${ }^{3}$, Mihai Cristian DUMITRAŞCU ${ }^{3,5}$, \\ Daniela Oana TOADER ${ }^{3,6}$, Agnes K. LACKNER ${ }^{8}$, Elena POPESCU ${ }^{3,9}$
}

${ }^{1}$ Institutul Național pentru Recuperare, Medicină fizică şi Balneoclimatologie, Bucureşti, România ${ }^{2}$ Disciplina de Biochimie, Facultatea de Medicină Dentară, Universitatea de Medicină şi Farmacie „Carol Davila“, Bucureşti, România

${ }^{3}$ Universitatea de Medicină şi Farmacie „Carol Davila“, Bucureşti, România ${ }^{4}$ Spitalul Universitar de Urgență Elias, Bucureşti, România ${ }^{5}$ Spitalul Universitar de Urgență, Bucureşti, România

${ }^{6}$ Institutul Național pentru Sănătatea Mamei şi a Copilului „Alessandrescu-Rusescu“, Clinica Polizu, Obstetrică-Ginecologie şi Neonatologie, Bucureşti, România

${ }^{7}$ Institutul Național pentru Sănătatea Mamei şi a Copilului „Alessandrescu-Rusescu“, Laboratorul de cercetare în Pediatrie şi Obstetrică Socială, Bucureşti, România

${ }^{8}$ Department of Paediatric Dentistry, University Dental Clinic, Medical University, Vienna, Austria ${ }^{9}$ Spitalul Clinic Județean de Urgență Ilfov, Bucureşti, România

\begin{abstract}
Oral candidiasis is an infection of the oral cavity caused by Candida albicans. Several factors may contribute to the development of candidiasis such as: use of prostheses, corticosteroid inhalers, xerostomia, immunosuppressed states (such as human immunodeficiency virus (HIV), leukemia, malnutrition, decreased secondary immunity, endocrine dysfunction, chemo, diabetes, such as systemic, radiation therapy, use of systemic corticosteroids).
\end{abstract}

Keywords: oral candidiasis, clinical forms, cheilitis

\section{REZUMAT}

Candidoza orală este o infecție a cavității orale cauzată de către Candida albicans. Mai mulți factori pot contribui la dezvoltarea candidozei precum: utilizarea protezelor, inhalatoarelor de corticosteroizi, xerostomia, stări de imunosupresie (cum ar fi infecția cu virusul imunodeficienței umane (HIV), leucemie, malnutriție, scăderea imunității secundară vârstei, disfuncție endocrină, cum ar fi diabetul, chimioterapie sistemică, terapie cu radiații, utilizarea de corticosteroizi sistemici).

Cuvinte cheie: candidoză orală, forme clinice, cheilită 


\section{INTRODUCERE}

Candidoza orală este o infecție a cavității orale cauzată de către Candida albicans. Candidoza orală a fost relatată pentru prima dată de către François Veilleux în anul 1838. Candida este prezentă în flora orală la persoanele sănătoase, unele estimări arată o prezență de 45-65\% dintre sugarii sănătoși și 30-55\% dintre adulții sănătoși (1).

La om, cea mai frecventă specie de Candida care se găsește atât în mucoasa orală sănătoasă, cât și în candidoza orală este $C$. albicans, din cauza proprietăților sale de aderență și a unui nivel mai mare de patogenitate, fiind izolată în mai mult de $80 \%$ dintre leziunile orale (2). Alte specii care pot fi implicate mai rar în candidoza orală includ $C$. dubliniensis, C. glabrata, C. krusei, C. kefyr, C. parapsilosis, $C$. stellatoidea și $C$. tropicalis; aceste specii colonizează mai mult pacienții cu vârsta de peste 80 de ani față de pacienții mai tineri $(3,4)$.

Mai mulți factori pot contribui la dezvoltarea candidozei precum: utilizarea protezelor, a inhalatoarelor de corticosteroizi, xerostomia, stări de imunosupresie -virusul imunodeficienței umane HIV), leucemie, malnutriție, scăderea imunității secundare vârstei, disfuncții endocrine (diabetul), chimioterapie sistemică, terapie cu radiații, utilizarea de corticosteroizi sistemici -, medicamente imunomodulatoare, medicamente xerogenice și antimicrobiene cu spectru larg; mai nou, inclusiv psoriazisul este considerat un factor predispozant $(5,6,7,8,9)$.

Candidoza orală afectează în mod egal ambele sexe. Apare de obicei la nou-născuți și sugari, însă mai rar în prima săptămână de viață și după vârsta de 6 luni. Este transmisibilă prin sărut, precum și prin alăptare. La pacienții sănătoși, de obicei, sistemul imunitar al pacientului și flora normală a bacteriilor inhibă creșterea Candidei. În consecință, imunosupresia indusă de condiții precum diabetul, fumatul, folosirea de proteze, consumul de steroizi, malnutriția, deficiențele de vitamine și utilizarea recentă de antibiotice duce adesea la boală $(10,11)$.

\section{ASPECTE CLINICE}

Pacienții vor prezenta, în general, leziuni de nuanță albă pe limbă și/sau mucoasa bucală. Leziunile sunt provocate în urma unei stări de imunosupresie (fumatul, utilizarea antibioticelor, steroizilor, medicamentele imunosupresive la pacienții cu transplant, utilizarea protezelor dentare, malnutriția etc.).

Candidoza orală se prezintă ca albă sau eritematoasă. Candidoza orală albă se caracterizează prin leziuni albe, inclusiv candidoză pseudomembranoasă și candidoză hiperplastică. Candidoza orală eritematoasă se caracterizează prin leziuni roșii, incluzând candidoză atrofică acută, candidoză atrofică cronică, glosită romboidă mediană, cheilită unghiulară și eritem gingival liniar. Pe lângă aceste forme, există și altele care nu se încadrează în categoriile de mai sus, și anume candidoza mucocutanată cronică, cheilocandidioza și candidoza multifocală cronică.

Candidoza orală constă, de obicei, din plăci pseudomembranoase albe dificil de îndepărtat, ce afectează mucoasa bucală, limba, palatul dur și moale. Se asociază cu pierderea gustului, cu cheilitis unghiular și de obicei nu sunt dureroase. După răzuirea plăcilor, rămân adesea leziuni inflamate, dureroase, care pot sângera. Candidoza poate fi prezentă și în alte părți ale corpului.

\section{Candidoza orală albă}

Candidoza pseudomembranoasă este prezentarea clasică a candidozei orale. Deși de obicei este asimptomatică, poate apărea o senzație de arsură orală, modificări în percepția gustului, un gust acru sau tendința de sângerare ușoară la locurile afectate (12). Leziuni pot fi acute sau cronice; plăcile albe se pot șterge ușor cu tifon, lăsând în urmă o suprafață eritematoasă. Cel mai adesea apare la persoanele imunodeprimate, de asemenea, sunt afectate persoanele vârstnice și sugarii (13).

Candidoză hiperplastică este reprezentată de plăci albe bine circumscrise, ușor ridicate, cel mai frecvent aderente la mucoasa bucală. Leziunile pot fi atât dimensiuni mici translucide, cât și de dimensiuni mari opace (14). Candidoza hiperplastică se găsește rar pe limbă sau pe palat. În cazul candidozei hiperplastice, plăcile nu pot fi înlăturate cu ușurință. Candidoza hiperplastică a fost asociată cu modificări crescute maligne în comparație cu leucoplazia noncandidală (14).

\section{Candidoză orală eritematoasă}

Candidoza atrofică acută se prezintă sub formă de plasturi eritematoase, cel mai frecvent pe palat, în special la pacienții cu HIV (15). Patch-uri eritematoase pot fi prezente pe mucoasa bucală sau limbă, de asemenea poate fi prezentă atrofie. Pacientul poate acuza o senzație de arsură la nivelul gurii și durere la nivelul buzelor și limbii (16). Factorii predispozanți pentru dezvoltarea candidozei atrofice acute includ: antibiotice cu spectru larg (cresc riscul pentru supraaglomerarea C. albicans prin scăderea florei bacteriene normale la nivel bucal), corticosteroizii, HIV, diabetul zaharat necontrolat, anemia cu deficit de fier și deficiența de vitamina B12 $(17,18,19,20)$. 
Candidoza atrofică cronică apare la persoanele cu proteze, de obicei cele prost montate ocluzează mucoasa bucală și inhibă fluxul salivar, ceea ce duce la supraîncărcarea cu Candida. Leziunile sunt eritematoase, edematoase și sunt limitate în mod caracteristic la mucoasa bucală, poate fi prezent cheilitis unghiular. Tipurile candidozei atrofice:

- Tipul I este limitat la semnele locale de boală cu hemoragie petechială identificată și inflamație locală.

- Tipul II se prezintă ca eritem al mucoasei în contact cu proteza dentară.

- Tipul III descrie eritemul palatului dur central sau cu hiperplazia papilară a mucoasei bucale în contact cu proteza dentară.

Cheilita unghiulară (stomatita unghiulară), prezintă zone eritematoase, fisurate de-a lungul comisurilor gurii. Este de obicei bilaterală și însoțită de durere. Dezvoltarea acestei afecțiuni ține atât de C. albicans cât și de Staphylococcus aureus $(21,22)$. De obicei, apare la purtătorii de proteze dentare, la cei care își ling buzele și își mușcă colțurile gurii, de asemenea, la cei cu deficiență de acid folic, fier, riboflavină, tiamină și vitamina B12 (23).

Eritemul gingival liniar apare ca o bandă eritematoasă discretă de-a lungul marjei gingivale a unuia sau mai multor dinți. Această afecțiune poate fi cauzată atât de infecțiile cu candidoză, cât și de infecțiile bacteriene și poate fi considerată marker clinic în infecția HIV dar poate fi dezvoltată și de către copii sănătoși $(24,25)$.

\section{ALTE FORME DE CANDIDOZĂ ORALĂ}

Candidoza mucocutanată cronică este o afecțiune eterogenă, în cadrul căreia se evidențiază leziuni cronice orale (cheilită unghiulară, candidoză hiperplastică și cheilită pseudomembranoasă), cutanate (suprafețele acrale și scalpul evidențiază plăci eritematoase hiperkeratotice), dar și unghiale. Această formă este de obicei legată de disfuncția imunitară și are un răspuns slab la agenți antifungici topici $(17,26,27)$. Se asociază cu anomalii endocrine și formează un set rar de sindroame, inclusiv poliendocrinopatie autoimună-candidozădistrofie ectodermică și sindrom endocrino-candidoză. Anomaliile endocrine care au fost asociate cu această formă de candidoză includ diabetul zaharat, hipoparatiroidismul și boala Addison $(17,28)$.

Cheilocandidioza este reprezentată de o leziune ulceroasă localizată pe buză, de regulă pe marginea inferioară a vermilionului (12).

Candidoza multifocală cronică prezintă plăci eritematoase în două sau mai multe locuri ale gurii. Afectează, de obicei, persoanele de sex masculin mai în vârstă și fumători. Criteriile pentru această afecțiune includ leziunile care sunt prezente mai mult de 4 săptămâni și în absența factorilor de risc identificabili (29).

\section{ASPECTE DIAGNOSTICE}

Pe lângă examenul clinic, diagnosticul poate fi confirmat prin obținerea unui frotiu, probă de clătire orală, probă de salivă integrală sau efectuarea unei biopsii orale (30). Candidoza pseudomembranoasă poate fi confirmată prin obținerea unui frotiu de citologie sau a unui specimen de biopsie al leziunii și aplicarea colorației PAS pe eșantion.

Când se suspectează diagnosticul de candidoză orală la un pacient cu leziuni orale, diagnosticul diferențial se face cu leucoplazia păroasă orală (o afecțiune declanșată de virusul Epstein-Barr), angioedem, stomatită aftoasă, herpes, gingivostomatită, herpes labialis, rujeola (pete Koplik) (31). Vor fi luate în considerare și: dermatita periorală, sindromul Stevens-Johnson, histiocitoza, blastomicoza, limfohistiocitoza, difteria, esofagita, sifilisul, faringita streptococică, lichenul plan, arsurile chimice și traumatismele.

\section{CONCLUZII}

Candidoza orală poate să apară în mai multe forme. Fiecare formă este caracteristică fie unor afecțiuni asociate, fie unei anumite categorii de persoane. Atât aspectul fiecărei forme, cât și complianța la tratament diferă. Sunt importante aspectul diagnosticului diferențial și metoda de confirmare a diagnosticului.

\section{Mențiune}

Toți autorii au contribuție egală.

Conflict of interest: none declared Financial support: none declared

\section{BIBLIOGRAFIE}

1. Arendorf TM, Walker DM. The prevalence and intra-oral distribution of Candida albicans in man. Arch Oral Biol 1980; 25:1-10.
2. Zegarelli DJ. Fungal infections of the oral cavity. Otolaryngol Clin North Am 1993; 26:1069-1089.

3. Al-Karaawi ZM, Manfredi M, Waugh AC, et al. Molecular characterization of Candida spp. isolated from the oral cavities of patients from diverse clinical settings. Oral Microbiol Immunol 2002;17:44-49. 
4. Benito-Cruz B, Aranda-Romo S, LópezEsqueda FJ, de la Rosa-García E, Rosas-Hernández R, Sánchez-Vargas LO. Oral Candida isolates and fluconazole susceptibility patterns in older Mexican women. Arch Gerontol Geriatr. 2016; 65:204-10.

5. Olariu C, Nurciu A, Vasilescu I, et al. Afectarea măduvei hematogene la pacienţii cu infecţie HIV. Practica Medicală 2018; 13,2(57):156-161.

6. Bejan GC, Stănescu AMA, Ghilencea NL, Matei $\mathrm{D}$. Analiza actuală a aspectelor terapeutice moderne în tratamentul HTA şi al comorbidităţilor asociate. Revista Medicală Romana 2018; LXV(2):102-107.

7. Stănescu AMA, Grajdeanu IV, Bejan GC, Bratu OG, Kozma A, Codreanu IF, Diaconu CC. Predicţia prevalenţei HIV pană în anul 2022 în România şi Uniunea Europeană. Revista Medicală Română 2018; $\operatorname{LXV}(4): 261-265$.

8. Kozma A, Ursu E, Oancea R, et al. Minimal invasive oro-dental procedures recommendations for optimal care in children with haemophilia. Practica Medicală 2018; 13,4(61):267-270.

9. Stănescu AMA, Matei A, Grăjdeanu IV, Appiah EA, Giurcăneanu C. Multipli factori de interes în managementul psoriazisului şi comorbidităţilor asociate. Practica Medicală 2016; 11,1(43):49-52.

10. Stefani C, Grajdeanu IV, Serban B, et al. Importanţa cunoaşterii manifestărilor cutanate fiziologice în sarcină pentru managementul corect al afecţiunilor cutanate în sarcină. Practica Medicală 2019; 14,1(64):26-29.

11. Stănescu AMA, Grajdeanu IV, lancu MA, Ştefani C, Şerban B, Bratu OG, Socea B, Diaconu CC. Verucile genitale şi vulvovaginita candidozică în timpul sarcinii - actualităţi şi posibilităţi terapeutice. Revista Medicală Română 2019; LXVI(2):114-117.
12. Sharon V, Fazel N. Oral candidiasis and angular cheilitis. Dermatol Ther 2010; 23:230-242.

13. Patton LL. Oral lesions associated with human immunodeficiency virus disease. Dent Clin North Am 2013;57:673-698.

14. McCullough MJ, Savage NW. Oral candidiasis and the therapeutic use of antifungal agents in dentistry. Aust Dent $J$ 2005;50:S36-S39.

15. Akpan A, Morgan R. Oral candidiasis. Postgrad Med J 2002;78:455-459.

16. Samaranayake LP, Keung Leung W, Jin L. Oral mucosal fungal infections. Periodontol 2000-2009;49:39-59.

17. Giannini PJ, Shetty KV. Diagnosis and management of oral candidiasis. Otolaryngol Clin North Am 2011;44:231-240.

18. Gheorghe G, Ceobanu G, llie M, et al. Gastrointestinal and neurological manifestations in systemic lupus erythematosus. Arch Balk Med Union 2019; 54(3):555-560.

19. Stănescu AMA, Grajdeanu IV, Serban B, Bratu OG, Diaconu CC. Importanţa supradiagnosticării în medicina de familie. Cum minimalizăm riscurile? Revista Medicală Română 2019;LXVI(1):29-33.

20. Diaconu C, Bălăceanu A, Bartoş D. Diuretics, first-line antihypertensive agents: are they always safe in the elderly? Romanian Journal of Internal Medicine 2014; 52(2):87-90.

21. Wilkieson C, Samaranayake LP, MacFarlane TW, et al. Oral candidiasis in the elderly in long term hospital care. J Oral Pathol Med 1991;20:13-16.

22. Marcu RD, Spînu AD, Socea B, Bodean OM, Diaconu CC, Vasilescu F, Neagu TP, Bratu OG. Castleman's disease - clinical, histological and therapeutic features. Rev Chim (Bucharest) 2018;69(4): 823-830.

23. Appleton SS. Candidiasis: pathogenesis, clinical characteristics, and treatment. $J$ Calif Dent Assoc 2000; 28:942-948.
24. Odden K, Schenck K, Koppang H, et al. Candidal infection of the gingiva in HIV-infected persons. J Oral Pathol Med 1994; 23:178-183.

25. Mircescu D, Totan A, Stanescu II, et al. Periodontal disease and systemic health. Revista Medicală Română 2019; LXVI(3):195-199.

26. Stănescu AMA, Grajdeanu IV, Stefani $C$, Serban B, Diaconu CC. O meta-analiză a studiilor observaţionale privind sindromul metabolic ca o comorbiditate a psoriazisului. Revista Medicală Română 2019; LXVI(1):24-28.

27. Diaconu C, Bălăceanu A, Bartoş D. Venous thromboembolism in pregnant woman - a challenge for the clinician. Central European Journal of Medicine 2013; 8(5):548-552.

28. Kozma A, Forna DA, Radoi V, et al. Isolated dentinogenesis imperfecta and in association with osteogenesis imperfecta - a literature review. Revista Medicală Română 2018; LXV(4):258-260.

29. Bodean O, Bratu OG, Bohîltea R, Munteanu $O$, Marcu D, Spînu DA, Văcăroiu IA, Socea B, Diaconu CC, Fometescu Grădinaru D, Cîrstoiu M. The efficacy of synthetic oral progestin pills in patients with severe endometriosis. Rev Chim (Bucharest) 2018; 69(6):1411-1415.

30. Williams DW, Lewis MA. Isolation and identification of Candida from the oral cavity. Oral Dis 2000; 6:3-11.

31. Bratu OG, Marcu RD, Socea B, Neagu TP, Diaconu CC, Scârneciu I, Turcu FL, Rădăvoi GD, Brătilă E, Berceanu C, Spînu AD. Immunohistochemistry particularities of retroperitoneal tumors. Rev Chim (Bucharest) 2018;69(7):1813-1816. 